\title{
The Effect on Unfavourable Economic Conditions in Malaysia to Abandoned Housing Project
}

\author{
Nur Farhayu Ariffin, Saidah Annisaa Salam, Adib Danial Kamaruddin
}

\begin{abstract}
Abandoned of housing projects during construction is a prevailing problem that the housing sector in Malaysia has been experiencing since 1980s. This paper aims to highlight the causes and impacts of economic growth towards the abandoned housing projects. Factors pertaining to projects abandonment can be categorized into economic, financial, legal, managerial, system-related, and unforeseen risks. The study reveals main impacts of abandoned housing projects which is economic impacts. For this purpose, the study looks into how the extent of the impact of rising raw material prices, labour wage prices and transport machinery prices especially in Peninsular Malaysia towards the growth of number in abandoned housing project.
\end{abstract}

Keywords: Abandoned housing project, construction cost, peninsular Malaysia

\section{INTRODUCTION}

Growth in the value of construction work in Malaysia grew by $0.8 \%$ form previous year as states by department of statistic Malaysia [1]. From the figure, the value of construction work done in the second quarter 2019 recorded a growth of 0.8 per cent year-on-year, amounting to RM35.9 billion (Q1 2019: RM37.4 billion). The expansion in value of construction work done was driven by positive growth in the Civil engineering sub-sector with 8.2 per cent and Special trade's activities sub-sector with 5.9 per cent. However, the Residential buildings sub-sector and Nonresidential buildings sub-sectors growth reduced to $1.1 \mathrm{per}$ cent and 9.3 per cent respectively. The Civil engineering sub-sector remained as the key contributor to the value of construction work done with 44.8 per cent share. This was followed by Non-residential buildings (25.3\%), Residential buildings $(24.5 \%)$ and Special trade's activities $(5.4 \%)$. The private sector continued to propel the construction activity with 55.2 per cent share of value of construction work done (RM19.8 billion) as compared to the public sector with 44.8 per cent share of value of construction work done (RM16.1 billion). On the other hand, according to [2], the construction sector recorded value of gross output RM204.4 billion in 2017 compared to RM177.9 billion in 2015 with an annual growth rate of 7.2 per cent per annum. In line with the rapid growth in gross output, the value of intermediate input also increased by RM17.0 billion to RM131.8 billion with an annual growth rate of 7.2 per cent, thus resulting a value added of RM72.6 billion in 2017 as shown in fig. 2. This indicates that the construction project is still the main dominant in the growth of Malaysia's economy.

Revised Manuscript Received on October 22, 2019.

First Author: Nur Farhayu Ariffin, Senior Lecturer, Universiti Malaysia Pahang.

Second Author: Saidah Annisaa Salam, Postgraduate Student, Universiti Malaysia Pahang.

Third Author: Adib Danial Kamaruddin, Student, Universiti Malaysia Pahang.
The construction industry especially the housing development is one of an important economy influences for the Malaysian regardless of private or government sector. The industry is not only playing it important role for its finished product, but it also promotes employment opportunity. Therefore, the industry itself has a tremendous effect on the economy of a country during the actual construction process.

Despite of the various benefits provided by the construction industry to the Malaysian country, it was observable that the construction players are facing project failure including project delays, cost overrun, low productivity and unsafe site condition was among the criteria that affected the construction industry in Malaysia [3]. Among those, it was found that the worst scenario in the construction project is the abandoned project. The construction sector in Malaysia has struggled with financial difficulties which have led to many problems associated with abandoned projects [4]. The abandoned housing project in Malaysia is considered as a major problem and need a necessary action to mitigated [5].

Accelerated cases on abandoned project has been fuelled by strengthening domestic demand, improved labour market conditions, and wage growth, as well as improved external demand for Malaysia's manufactured products and commodity exports. The capital expenditure has also increased due to higher private and public investment [6]. The increase in the price of essential goods has been a huge impact on the lives of Malaysians on a regular basis overall. The rise in price of this item directly contributes to a higher cost of living [7]. By default, the higher the theoretical cost, the less power the consumer buys. [7] also added that for individuals, inflation will decrease true income and this situation will be serious if the rate of inflation or inflation rate is much higher than that the rate of increase in individual money income that will affect the buying power and the quality of their lives. The impact of the increase in prices has also affected the construction industry. Uncontrolled raw material price increases, raise of labour wage price, the different gaps in home price competition are some of the examples that are taking place [8].

Therefore, to overcome the issues, this study is focusing on finding out the real problems and situation affecting the indefinitely delayed construction project or abandoned construction buildings due to the economic growth. 


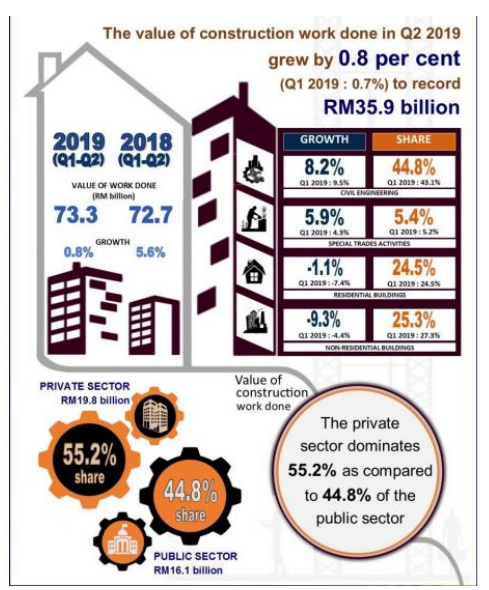

Fig. 1: The value of construction work in 2019 Source: Department of Statistics Malaysia [1]

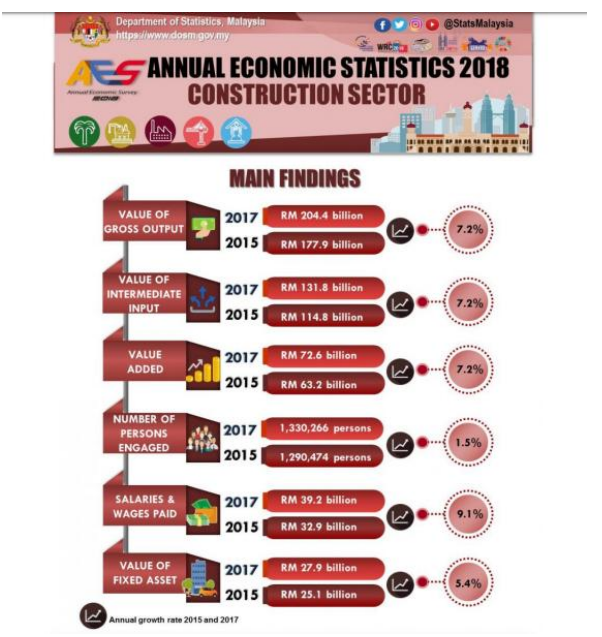

Fig. 2: The value of construction work in 2019 Source: Department of Statistics Malaysia [2]

\section{METHODOLOGY}

In this study, analyses of the data were obtained from the local authorities' department. The survey is to collect the data and trends of abandoned project especially housing project in Malaysia as well as the materials, workmanship and transportation cost for construction industry. The data collected by has been compiled from the annual Statistic of the National Housing Department (NHD), in order to convey the message of the various stakeholders regarding housing affairs regulated by NHD.

This results also discussed the point of the relationship between abandoned housing trends with prices of goods, abandoned housing trends with workforce and abandoned housing trends with transport machinery.

\section{RESULTS AND DISCUSSIONS}

\section{A. Number of abandoned project}

The area of this research cover all over the Peninsular Malaysia. Fig 1 shows the overall status of abandoned housing projects from year 2009 to 2018. Based on the fig., Selangor recorded the highest numbers of abandoned project. This is due to the numbers of construction project in Selangor is higher compare to other states. On the other hand, Perlis recorded the lowest number of abandoned housing project in year 2017.

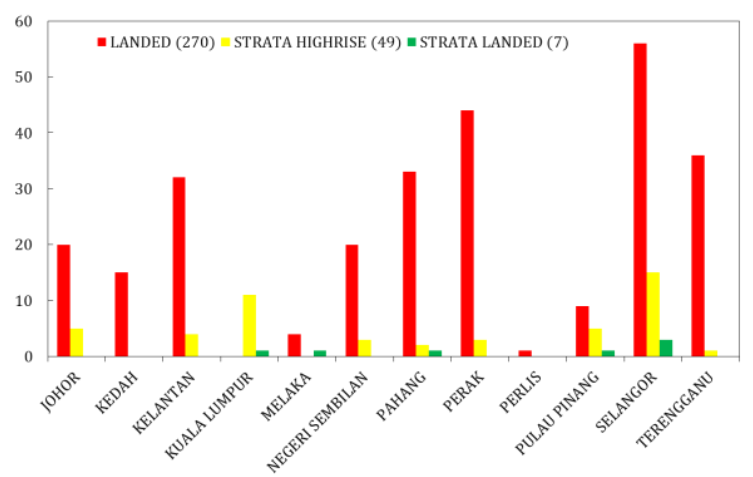

Fig 1. Numbers of abandoned house project in year 2017

Source: Abandoned Project Rehabilitation Division, National Housing Department 2017

Table I: Status of abandoned house project 2011 to 2017

\begin{tabular}{cccc}
\hline Year & $\begin{array}{c}\text { Current } \\
\text { project }\end{array}$ & $\begin{array}{c}\text { New } \\
\text { project }\end{array}$ & $\begin{array}{c}\text { Project } \\
\text { Finish }\end{array}$ \\
\hline 2011 & 110 & 6 & 32 \\
2012 & 84 & 11 & 35 \\
2013 & 60 & 27 & 30 \\
2014 & 57 & 10 & 15 \\
2015 & 52 & 11 & 15 \\
2016 & 48 & 26 & 8 \\
2017 & 47 & 15 & 192 \\
\hline
\end{tabular}

* Statistic of abandoned house project according to State [9] (Sources: Bahagian Pemulihan Projek terbengkalai,2017)

\section{B. Analysis on construction project cost}

In this section, will discuss the extent to which the impact of the rise in the price of goods on the rate of increase in the number of abandoned houses. The development of the construction industry has given rise to the growth of various building materials. Building materials comprise natural substances such as s and, wood, rocks, etc. or manufactured materials such as concrete, metal, cement, glass, etc. The CIDB classifies building materials into 17 categories which is cement, aggregate, sand, steel reinforcement, ready mix concrete, bricks, roofing, walls and floor tiles, ceiling board, plumbing works, sanitary fittings, paints, steel and metal sections, plywood timber, glass, ironmongery.

This study will cover three (3) market review building materials - cement, steel (with a focus on long steel) and ready-mixed concrete, which accounted for close to $60 \%$ of the total estimated value of materials used in construction projects. The scope of this review focuses on understanding the market structure, industry players, pricing trends, market concentration /dominance and competition concerns. 


\section{i. Materials}

\section{a) Cement}

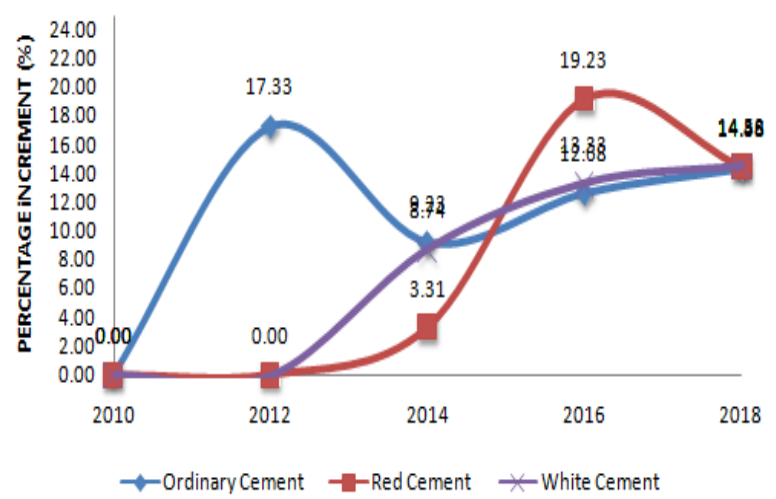

Fig 2. Percentage of price increments for cement

In the cement industry, the manufacturers have enjoyed continuous growth in demand since 2010. However, supply exceeded demand in 2016 due to overcapacity and contraction in local demand. This led to intense price pressure in 2016. Although improvement has been observed in the second half of 2017, the issues with extra capacity and slow growth in demand are expected to continue for the rest of the year. The Fig 2 shows the price of Ordinary cement, Red cement and White cement increase every year since 2010 [10].

\section{b) Steel Reinforcement}

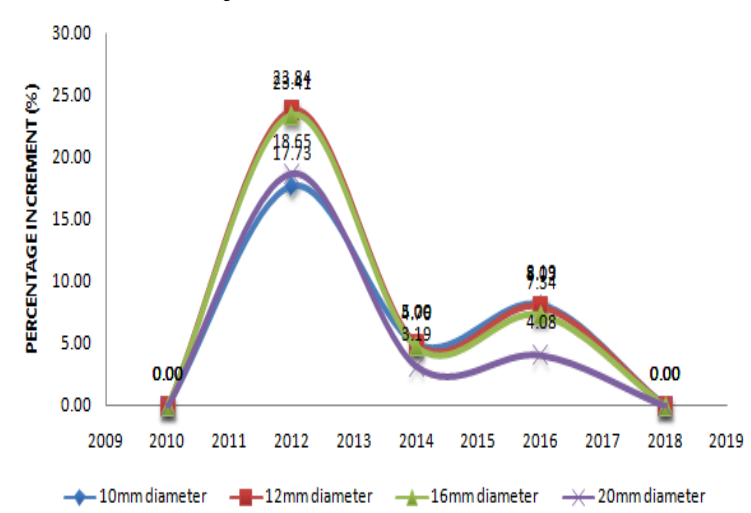

Fig 3. Percentage of price increments for steel reinforcement

Fig 3 shows, average market price of round bars (Y10 / Y12 / Y16 / Y20) was RM1,700 and RM2,500 per MT from year 2010 to 2018 in Peninsular and East Malaysia respectively. The main cost components in steel making, excluding capital expenditure, are raw materials which account for up to $70 \%$ of total production cost (mainly scrap metal or iron ore) and energy.

\section{c) Ready-mix concrete}

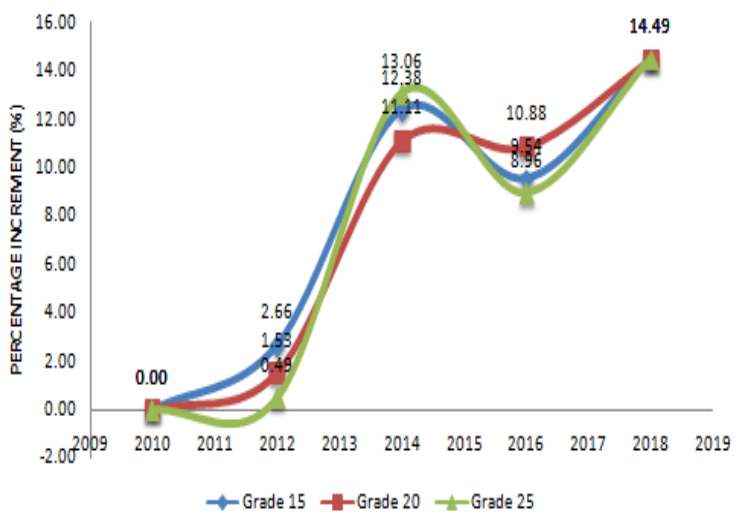

Fig 4. Percentage of price increments for ready-mix concrete

On the other hand, ready-mixed concrete production is much less capital intensive with a lot more players involved. There are an estimated 150 companies with about 10 large companies and approximately 1,000 batching plants in 2017 [10]. Some of the large players are owned by companies which are involved in cement manufacturing. Average market price of Grade 15 and Grade 20 normal mix was RM140 and RM203 per cubic meter, and for Grade 25 was RM 150 to RM215 from year 2010 to 2018 in Peninsular and East Malaysia respectively. Fig 4 shows the price increment of ready-mix concrete grows from year 2010 to 2015 but suddenly bottomed out in year 2016 and grew back on year 2017.

\section{ii. Workforce}

Zoning by State

$\begin{array}{ll}\text { Zone A } & \text { Selangor \& Negeri Sembilan } \\ \text { Zone B } & \text { Johor } \\ \text { Zone C } & \text { Pahang }\end{array}$

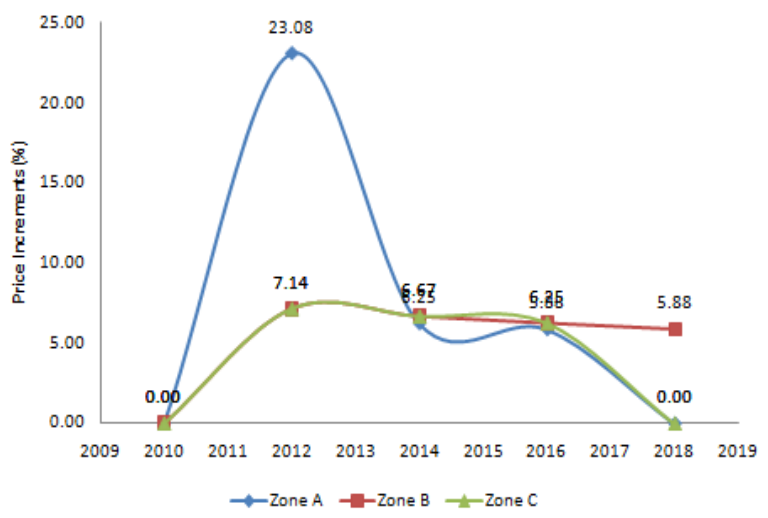

Fig 5. Price increment from year 2010 to 2018 for Tukang Bata 


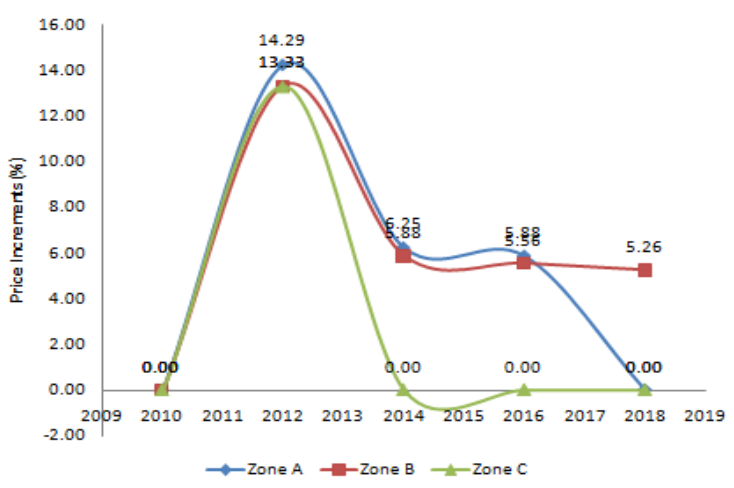

Fig 6. Price increment from year 2010 to 2018 for Tukang Besi

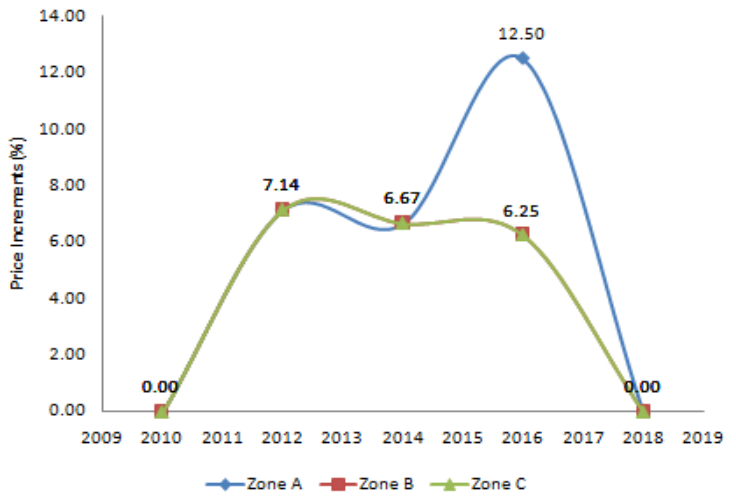

Fig 7. Price increment from year 2010 to 2018 for Tukang Konkrit

Based on the Fig 5, Fig 6 and Fig 7 above, Zone A, Zone $\mathrm{B}$ and Zone $\mathrm{C}$ shows the rate price of labour work increases every year [10]. By comparing among the three jobs above, the Tukang Besi showed a high increase compared to Tukang Batu and Tukang Konkrit in previous 8 years. Tukang Besi in Zone A that representing for State of Selangor shows dramatically increment in year 2012 with 14.29 percent compare to Zone B and Zone C with 13.3 percent. The rate returns equal with other work in year 2014 and suddenly drop to no changes in year 2018. For Zone B, which represents Johor, the price did not show a high increase which 13.33 percent in 2012, and steadily decrease in 3 years after with average 6.3 percent. Other work such as Tukang Batu and Tukang Konkrit, the increase in the price of goods only takes place in year 2012 by 7.14 percent and returns decline in the next 2 years by 5.88 percent and 5.56 percent.

As a result, among all the work being studied, Tukang Besi shows a high increase each year in terms of price compared to other jobs in all zones.

\section{iii. $\quad$ Transport Machinery}

\section{Zoning by State}

$\begin{array}{ll}\text { Zone A } & \text { Selangor \& Negeri Sembilan } \\ \text { Zone B } & \text { Johor } \\ \text { Zone C } & \text { Pahang }\end{array}$
$6.15 \%$ (RM 690) per day.
Fig 10. Price increment for Concrete Mixer in year 2010 to 2018

Usually rent rates include machinery, drivers and oils. Based on the Fig 8 above, the current rate ranges for excavator in Zone A, Zone B and Zone $\mathrm{C}$ in year 2010 from RM 650.00 to RM 700.00 However, in 2012, the price increase in Zone C rose sharply by $22.86 \%$ (RM 860) followed by Zone $\mathrm{B}$ with $10.77 \%$ (RM 720) and Zone A However, in 2014 the price 
dropped by $-6.98 \%$ to make the excavator rental price to RM800 a day. The decrease in rental price was also followed in the Zone B with a decrease of $-2.78 \%$. At Zone A, no increase has occurred during the next 6 years and maintains a rental price of RM 690 per day. the percentage increase in price has fluctuated over the next 4 years in Zone $\mathrm{B}$ and Zone $\mathrm{C}$.

For materials such as soil, concrete, cement, brick, timber and etc. are transported and transplanted from inside and outside the site using machinery such as lorries 5 tonne. Fig 9 shows in 2012, the three zones showed an increase in prices by $20 \%$ in Zone C, $15 \%$ in Zone A and $12.30 \%$ in Zone $\mathrm{B}$ and make the rental price for 5 tonne lorries at RM 420 to RM460 per day. In the next 6 years, the rental price decreased until 2018, all zones were at the same rate of 0 percent without improvement.

\section{Relationship between construction cost and numbers of abandoned house}

I. Number of abandoned project over Materials price increments

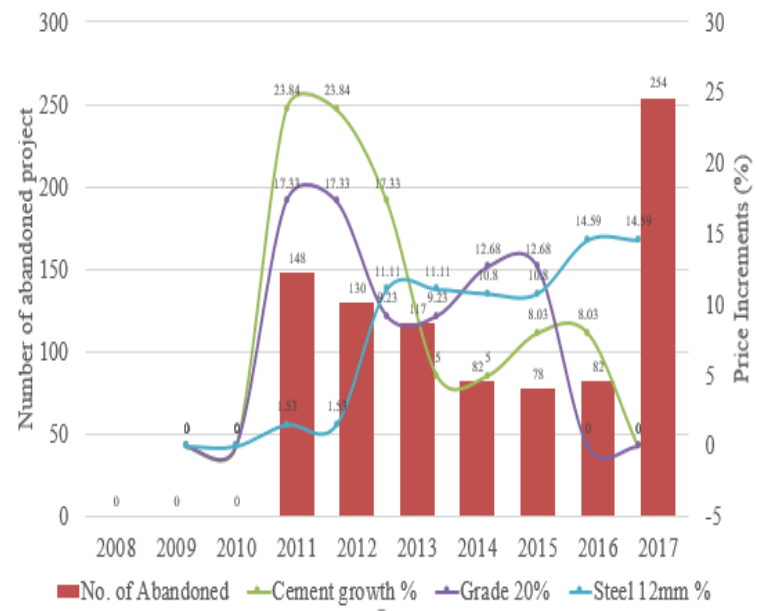

Fig 11. Number of abandoned project over Price increments of Materials

Based on the Fig 11, over the last 10 years the study found that material prices showed an increase in prices each year. This fluctuation graph occurs because of several factors such as high demand rate of materials that aligned with the increases in the number of approved projects and also the rate of imposition of GST tax on raw construction material. GST tax imposed on goods of $6 \%$ starting on April 1, 2015 has slightly affected the prices of goods in the construction industry. For example, ordinary cement price in year 2012-2014 (before GST implementation) cost RM14.20 per bag and has increased to RM16.00 per bag in year 20152016 and continuous increase with $14.3 \%$ percent (RM 18.30) per unit bag from the following year. This situation also take place for all types of construction materials.

As a result, the increase in the prices of goods with the implementation of GST in year 2015, affects the growth rate of the abandoned housing projects in year 2015 to 2017 with 191 projects.

\section{Number of abandoned project over Price increments of Workforce}

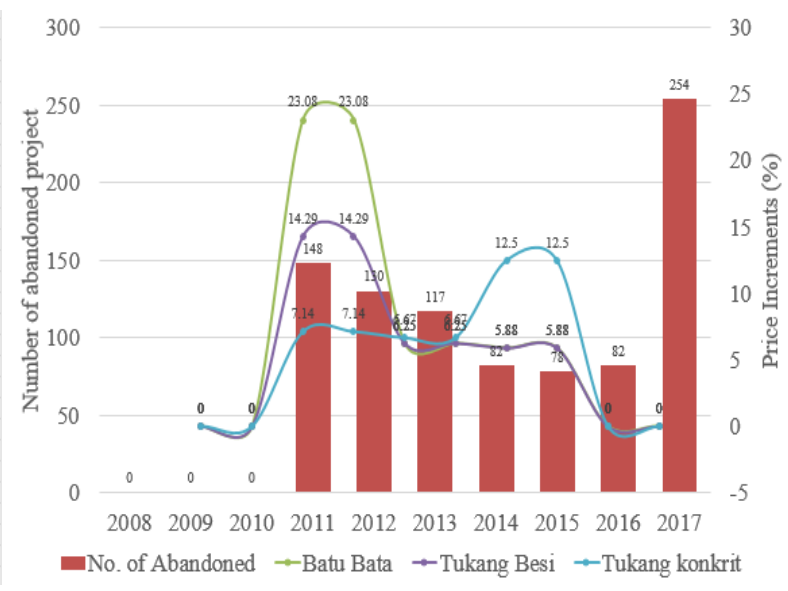

Fig 12. Number of abandoned project over Price increments of Workforce

As a result of the growth of the local construction industry, the construction sector requires a lot of workforce. The rapid development of the construction sector has led to high demand to the workforce. These high requirements cannot be met by local labour force and ultimately lead to high demand for foreign workforce. As a result, there is an outrageous dependency syndrome to foreign workers, as if the country was a desperate local manpower trained. However, this problem does not adversely affect the wage rate of the labour force. Based on Fig 12, the price for labour wages does not show a high increase every year. Started in year 2011, all wage costs deficits despite the number of abandoned house rising to 148 projects. In the following year, the price for the three workforce shows a reduction until in year 2016, there is no price increase. Although wage rates are decline, but the number of abandoned housing projects steadily increasing.

As can be conclude, the initial statement is contrary to the data obtained. Then it can be concluded, the rate of increase for the workforce is not significantly affect the numbers of abandoned project.

III. Number of abandoned project over transport Machinery price increments

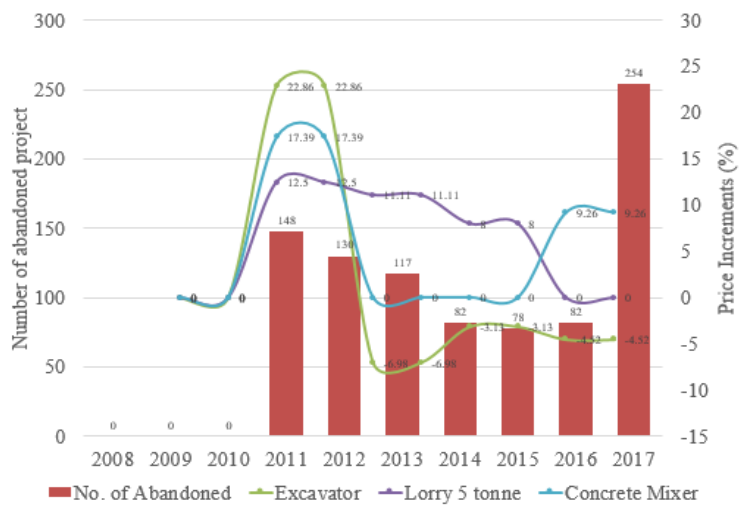

Fig 13. Number of abandoned project over Price increments of Transport Machinery

Published By: 
The rising prices of essential materials that burden the community, there has been an impact on other price increases as it involves this fuel source. Among of them is the housing construction industry which has a high impact on increases in oil prices [11]. For example, machinery equipment should be transported from place of production to construction site. The increase in oil costs and transportation costs will certainly be transferred to the contractor by raising the price of the final goods transported. One of the ways to overcome this problem is by maintaining a regular machine. Purchase of machinery equipment requires considerable start-up capital in addition to effective use planning. Such investments if taken into account in detail can contribute to speeding up the process build and save time and reduce labour costs. If the purchase of machinery equipment burdens the financial position of the contractor, the lease or purchase of the used equipment may be undertaken through a company which provides rental equipment on a contractual basis, daily rental or an agreed period of time. If seen at Fig 13, the 5 tonne concrete mixer and lorry machinery shows an increase each year compared to the excavator which declines in 2017.

\section{CONCLUSIONS}

The change in prices of construction costs affects the smoothness of constructing the project. The findings reveal that the rise in raw material prices for construction work affects construction project. It can begin with failure to complete the work within estimated period until the full failure of the project to be carried out causing the project to be abandoned.

As a conclusion, if it is to be made in the form of percentages for comparison between this three categories, therefore the cost of the raw material price is ranked $65 \%$, the transportation cost is $25 \%$ and the labour cost is $10 \%$ effect the abandoned of housing project growth.

\section{REFERENCES}

1. Department of Statistics Malaysia, Annual Economic Statistics 2018 Construction Sector, Press Release 9 August 2019.

2. Department of Statistics Malaysia, Annual Economic Statistics 2018 Construction Sector, Press Release 7 March 2019.

3. H. Abdul-rahman, C. Wang, and N. H. Ariffin, "Identification of Risks Pertaining to Abandoned Housing Projects in Malaysia" J. of Cons. Eng. Vol. 12, 2015

4. N. F. Ariffin, M. F. Md Jaafar, M. I. Ali, N. I. Ramli, K. Muthusamy, and N. H. Abdul Shukor Lim, "Investigation on factors that contribute to the abandonment of building in construction industry in Malaysia" E3S Web of Conf, Vol 34, (2018).

5. N. H. M. Dahlan, "The Need To Define " Abandoned Housing Project In Peninsular Malaysia: An Analysis" IIUM Law Journal, Vol 16, Issue (1), pp 85-107, (2008).

6. J. Bivens, "The potential macroeconomic benefits from increasing infrastructure investment," 2017. [Online]. Available: https://www.epi.org/files/pdf/130111.pdf.

7. M. A. A. Wahab, H. I. Shahiri, M. Mansur, and M. A. S. Zaidi, "The rising cost of living in Malaysia: A slow hh income growth or increasing standard of living," J. Ekon. Malaysia, vol. 52, no. 1, pp. 125-139, 2018

8. A. R. A. hamid \& N. A. Y. S.A.Mansur, "Rising Trend in Construction Cost and Housing," J. Adv. Res. Bus. Manag. Stud., vol. 3, no. January, pp. 94-104, 2016.

9. National Housing Department, "Perangkaan JPN 2017," 2017.

10. CIDB, "Construction Industries Review 2018-2019," 2019.

11. E. T. Glindro, T. Subhanij, J. Szeto, and H. Zhu, "Determinants of house prices in nine Asia-Pacific economies," Int. J. Cent.
Bank., vol. 7, no. 3, pp. 163-204, 2011.

\section{AUTHOR'S PROFILE}

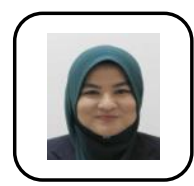

First Author: Nur Farhayu Ariffin is a senior lecturer in Universiti Malaysia Pahang. She completed Bachelor, Masters and $\mathrm{PhD}$ degree from Universiti Teknologi Malaysia and she has more than 15 publications published. She has been involved in multidisciplinary research projects in different fields since 2010. She has numbers of award winning research product and has various patented trademarked in Malaysian construction industry. Her associated professional membership includes: Concrete Society Malaysia (CSM) and Board of Engineering Malaysia (BEM).

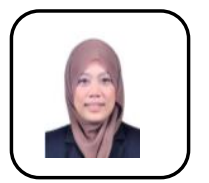

Second Author: Saidah Annisaa Salam is a postgraduate student at Universiti Malaysia Pahang. She completed Bachelor and Masters Degree from Universiti Teknologi Malaysia and she has more than 8 publications published. She is in her second year of $\mathrm{PhD}$ and also currently working as a project manager based in East Malaysia.

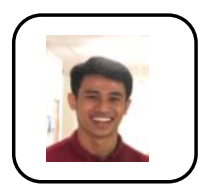

Third Author: Adib Danial Kamaruddin is a student at Universiti Malaysia Pahang. He is very active in research especially in construction project management. Currently he is an engineer based in southern region in Malaysia. 